\title{
Coming of Age in the Penal System: Neoliberalism, 'Mano Dura' and the Reproduction of 'Racialised' Inequality in Honduras
}

\author{
Lirio Gutiérrez Rivera, Iselin Åsedotter Strønen, \\ and Margit Ystanes
}

\begin{abstract}
INTRODUCTION
One of the ways in which colonially instituted 'racial' hierarchies are being reproduced in the Americas today, is through the penal system. The heightened levels of securitisation that accompanied the introduction of
\end{abstract}

Ethnographic research for this chapter was assisted by a grant from the Drugs, Security, and Democracy Program administered by the Social Science Research Council, in partnership with the Universidad de Los Andes (Colombia) and Centro de Investigación y Docencia Económicas, and in cooperation with funds provided by the Open Society Foundations.

L.G. Rivera $(\bowtie)$

Universidad Nacional de Colombia, Medellin, Colombia

I.Å. Strønen

University of Bergen and the Chr. Michelsen Institute (CMI), Bergen, Norway

M. Ystanes

University of Bergen, Bergen, Norway

(C) The Author(s) 2018

205

M. Ystanes, I.Å. Strønen (eds.), The Social Life of Economic

Inequalities in Contemporary Latin America, Approaches to Social

Inequality and Difference, DOI 10.1007/978-3-319-61536-3_9 
neoliberalism throughout the region, have particularly targeted 'racially othered' young males living in poor neighbourhoods. The Pink Tide did little, or nothing, to challenge this state of affairs. On the contrary, the targeting of 'racially othered,' poor, young males as criminals is a strong feature of securitisation in Brazil, Venezuela and Honduras alike, despite these countries' radically different engagements with the Pink Tide. The massive targeting of 'racially othered' poor, young, males in Latin America also has important similarities to processes of securitisation in the United States (see, e.g. Goffman 2014). In this chapter, we focus on the particular case of Honduras, yet we also draw comparisons with other countries that allow us to reflect upon the broader implications of the country's 'iron fist' approach to crime control. By doing so, we wish to emphasise how punitive control over 'surplus' populations in neoliberalised societies are informed by and contribute to the reproduction of historically constituted 'racial' and socio-economic hierarchies. As this chapter shows, the prison population in Honduras has not only dramatically increased in size, but once being inside the penitentiary system, the young prisoners end up passing important formative years in a system that has nothing to offer them in terms of rehabilitation or education. Whilst Honduras' socioeconomically better off can pay their way out of the prison system by legal or illegal means, poor men are systematically discriminated against even before they enter the prison. Indeed, the punitive profiling of certain groups of citizens, the inefficiency of the judicial system and the legal design of processual and penal codes indicates that the Honduran prison system is better understood as a place of containment for 'unwanted elements' than as an instrument for the rule of law.

The official justification for pursing an 'iron fist' approach towards crime in Honduras is the escalating levels of violence in the country during the past two decades. In the early 1990s, Salomón (1994) observed that a

Parts of this chapter have previously been published as part of the research project Everyday Manouvers. Military-Civilian Relations in Latin American and the Middle East, led by professor Nefissa Naguib and financed by the Norwegian Ministry for Foreign Affairs. The original paper was titled CMI Working Paper: Security and Remilitarization in the Name of Democracy: The Impact of Global Crime Control Policies in Honduras (2015). Lirio Gutiérrez Rivera et al. graciously acknowledges Professor Nefissa Naguib and the Chr. Michelsen Institute (CMI), Bergen, Norway, for permission to reprint. 
new type of violence was emerging that differed from the political violence in prior decades. This implied the gradual proliferation of criminal and delinquent acts such as armed robbery and theft, mostly involving male adolescents and young adults. Towards the end of the 1990s and early twenty-first century, various scholars recognised the emergence of 'new violence' in various post-conflict scenarios (Koonings and Kruijt 2004; Rotker 2002), ${ }^{1}$ including a variety of actors such as death squads, paramilitary groups, organised crime and youth gangs. In Honduras, youth gangs and, more recently, organised crime, proliferated. The former, known as the maras, appeared in the 1990s. Part of the reason why this happened was changes in the conditions for social reproduction, such as the family, the educational system and the labour market. These changes were brought about by the implementation of neoliberal policies, leading to increased poverty, inequality and unemployment. ${ }^{2}$ Today, around 60 per cent of the Honduran population live in poverty (UNDP 2014). Most of the population, particularly the youth segment, has been hit by the lack of job opportunities in the country, forcing many to immigrate mainly to the United States. In other cases, entering the illicit drug economy or joining the gangs becomes a solution to the difficulties of overcoming economic hardships and for finding a place for identity and belonging (Strocka 2006:139).

Another intersecting factor was the massive arrival of deportees from the United States with a background as active gang members in the 1990s. Shifts in the US migration policy led to the deportation of documented and undocumented migrants who had criminal records. Many of the deportees were members of two street gangs from Southern California: the Mara Salvatrucha and the Eighteenth Street Gang (Dieciocho). Shortly after returning 'home,' a place where many had never lived and which did not even exist in their childhood memories, the deportees, who were members of either one of the maras, reorganised and merged the gang with the existing local ones. Following these 'mergers' (there had been gangs in Honduras since the 1950s), street gangs' organisation became more complex due to increasing membership numbers, and the use of violence became more institutionalised (Salomón et al. 1999). However, even if the maras were framed as the main culprits for escalating violence and crime in the country, they were not the centre of the storm. Rather, organised crime was (Rodgers 2009; Jüttersonke et al. 2009; UNODC 2012). However, these networks are much more difficult to target, whilst 
also being tied to more powerful sectors in the country (Bosworth 2010; Shipley 2016).

Since the turn of the twenty-first century, the prison population in Honduras has been on the rise. Currently, there are 17,017 female and male inmates, out of a population of 8 million (World Prison Brief 2016). This is almost twice the number of prisoners in 2002 and three times more than in the late 1990s. In 2012, the prison population rate was at 152 of 100,000 per inhabitants. In 2014 , it had risen to $194 / 100,000$.

The Honduran government's security agenda is one of the main reasons for the increase of the inmate population. Introduced in 2002 by the administration of Ricardo Maduro (2002-2006) and continued by the subsequent administrations of president Manuel Zelaya (2006-2009), Porfirio Lobo (2010-2014) and Juan Orlando Hernández (2013-), the domestic security agenda has sought to reduce violence and crime by incarcerating not only convicted delinquents and criminals but also those who are perceived-judged by their physical appearances- to be associated with crime and gang membership. Typically, this includes clothing, tattoos and haircuts, but in practice, class- and ethno-racial identity markers is also enough to be singled out for arrest and imprisonment.

As we discuss further below, the 'iron fist' approach to crime taken by successive Honduran governments is typical of what Wacquant (2009) and others have theorised as an intrinsic part of the neoliberal state, a state that seeks to 'control' those who are structurally excluded and marginalised by the neoliberal order through an expanding punitive prison system. Thus, our purpose in this chapter is not to single out Honduras in particular for maintaining this neoliberal approach to securitisation. As other chapters show, even Brazil, which has been one of the leading forces of the Pink Tide, has done the same (see Sørbøe (Chap. 5); Ystanes (Chap. 4), this volume). Rather, we take the firm continuation of this agenda across the political spectrum as indicative of the scope of possibilities, and of imagination, of Latin American governments and the deepseated punitive ideology and structural features in which they are embedded. At the same time, Honduras' particular geopolitical context as part of the US War on Drugs, and the increasingly authoritarian stance taken by its ruling elites, points to an increasing consolidation of 'iron fist' security politics that is undercut by a general repressive stance towards marginalised and excluded groups. 


\section{The Pink Tide in Honduras: Zelaya’s Brief Interlude}

Honduras was briefly considered to be in the orbit of the so-called Pink Tide during Manuel Zelaya's presidency until he was ousted by the military and conservative elites in June 2009. Zelaya, a wealthy land and ranch owner belonging to one of the regional elites of the country, had been elected for the Liberal party in 2006. Initially, he took a slightly softer approach to security politics than his main contender, Porfirio Lobo. However, this softer stance never really came into effect, arguably because he was caught up in other economic and political issues (Bosworth 2010:19).

Whilst in office, Zelaya introduced free school enrolment, increased the minimum wage, increased wages for teachers and attempted to reduce fuel costs (Gordon and Webber 2011). Moreover, he reformed the mining laws, introducing a new bill that would raise tax on foreign mining companies, passed a Reforestation Law (Ley de Reforestación) designed to protect the environment and refused to privatise the state-owned electric and telecommunications companies.

The traditional elites and the military, though not happy with these reforms, did not initially feel threatened. Eventually, however, this attitude changed, mostly due to two of Zelaya's initiatives. Firstly, in 2008, Zelaya decided to join the Bolivarian Alliance for the Peoples of Our America (ALBA) led by Venezuela, in order to address an economic downturn in the country (Gordon and Webber 2011). Secondly, in 2009 Zelaya decided to call a referendum asking the Honduran population to vote for a new Constituent National Assembly that would reform the constitution. The traditional elites and the military, as well as other conservative sectors of civil society such as the Catholic Church, immediately reacted against Zelaya. They claimed the referendum was part of a plan for Zelaya to remain in power, and that he was becoming a puppet of Venezuelan president Hugo Chávez. ${ }^{3}$

The military refused to comply with Zelaya's order to distribute the ballots for the referendum scheduled to take place during the presidential elections in November 2009. Zelaya then fired the head of the Armed Forces, Gen. Romeo Orlando Vásquez Velásquez. Shortly thereafter, the Minister of Defense, Ángel Orellana, resigned. The Supreme Court ruled both the referendum and Gen. Vásquez's dismissal as illegal. In Congress, Roberto Micheletti from the Liberal party and president of Congress, as 
well as other members of the Liberal party, turned against Zelaya. This group, the right-wing faction of the Liberal party, allied with the military high officials, conservative groups such as the Catholic Church-especially the Opus Dei-and the traditional elites to overthrow Zelaya. ${ }^{4}$ On Sunday, June 28, Zelaya was ousted when the military arrived at Zelaya's home and sent him to Costa Rica in his pajamas. Roberto Micheletti became interim president until the new elections in November 2009. These elections were won by Porfirio 'Pepe' Lobo, who Shipley (2016:9) describes as 'a coup-supporter and member of the Honduran oligarchy.' Subsequent presidential elections in 2013 were won by Juan Orlando Hernández, who was president of Congress during Lobo's presidency. The elections were strongly criticised by international observers (Shipley 2016:12). In recent years, political violence, murder and persecution of dissent has escalated in Honduras (see Blitzer 2016; Hallinan 2009). Escalating violence and impunity has also been linked to US military funding and presence in Honduras, through the so-called War on Drugs (Grosso 2014; Shipley 2016). Honduras is now ranked as the world's most dangerous country for environmental activists (Global Witness 2017), an issue that received increasing international attention following the brutal murder of the internationally known environmental activist Berta Cáceres in 2016. In January 2017, Juan Orlando Hernández, a staunch ally of the United States, announced the he would seek re-election as president. Paradoxically, one of the main justifications for overthrowing Zelaya was concerns that he would change the constitution in order to do the same thing.

\section{Neoliberalism in Honduras}

Nearly 30 years of neoliberal reforms have not only left a wide gap between rich and poor in Honduras, but also they reinforced the racial and gender hierarchies established in the colonial period. This contemporary overlap between poverty and being 'racially othered' is, as discussed below and in the introduction to this volume, an outcome of long historical processes in the region.

The first attempts to introduce neoliberal reforms in Honduras occurred during the government of José Azcona Hoyo (1986-1990) under the supervision of USAID (Bull 2016:97). The United States had a strong military presence in Honduras during the 1980s, using Honduran territory as the base to launch its operations against the Sandinistas in Nicaragua. At the time, US ambassador John Negroponte was widely considered as 'the real power holder' in the country (Shipley 2016:5). The first structural 
adjustment programme was signed in 1988, whilst the government of Rafael Leonardo Callejas (1990-1994) implemented further reforms including economic liberalisation and the privatisation of state industry and public services (Bull 2016:97).

In general, neoliberal reforms favoured Central America's elites and dominant economic groups, who seized upon new opportunities in emerging private markets whilst simultaneously gaining access to global chains of production and capital with little state intervention (Robinson 2003; Bull et al. 2014; Bull 2016). However, these reforms also widened the gap between poor and rich. The privatisation of social services and economic liberalisation policies undermined both social security nets and opportunities in the labour market. The International Labour Organization (ILO) estimates that 70 per cent of new jobs over the past 15 years have been generated in the informal economy (ILO 2007:5). Furthermore, they estimate that some 75 per cent of workers in Latin America are involved in the informal economy, generating about 40 per cent of the continent's GDP (ILO 2007:5). As explanatory factors for this increasing size of the informal sectors, the organisation points to:

High rates of rural-urban migration, structural adjustment programs of the 1980s and 1990s and/or for some from burdensome regulations and lack of recognition of the property rights and capital of informal operators. (ILO 2007:5)

The reduction of the formal job market also resulted in the expansion of criminal economy, creating a new labour market for the least qualified part of the workforce (Ziccardi 2008:9). For Portes and Hoffman, it is 'perhaps remarkable' (Portes and Hoffman 2003:70) that only a small percentage of the informal proletariat has succumbed to crime in reaction to increasing impoverishment and marginalisation over the past decades.

Despite a relative and often absolute deterioration of their situation, the large majority of informal workers continue to toil at minimally paid domestic service, unprotected work in micro-enterprise, or by inventing some form of marginal activity. (Portes and Hoffman 2003:70)

In Honduras, neoliberal reforms in the agricultural sector also had severe ripple effects. The 1992 Decree of Modernisation and Development of the Agricultural Sector (Ley de Modernización y de Desarrollo del Sector Agricola) restructured traditional forms of production and land tenure 
by prioritising the development of agroindustry business. Campesinos (peasants) were unable to produce these types of crops because, contrary to the regional elites, they did not have access to credit or technology. Unable to sustain themselves, many peasants were forced to sell their lands to the growing agroindustry and migrated to the main cities (such as San Pedro Sula or Tegucigalpa) or even abroad (mainly the United States) in search of better economic opportunities. In the cities, however, many migrants become un- and/or underemployed, which in turn added to the crisis of urban marginality that is fuelling the negative cycle of structural inequality, violence and security politics in contemporary Honduras, affecting young men in particular.

\section{The Neoliberal Punitive State}

As Garland (2002) discusses, the 1970s marked the start of a significant international shift in crime control and the criminal justice system, which implied the transformation of various institutions and technologies for social control. Rather than the belief in the rehabilitation of criminals and delinquents that predominated until the 1970s, today's contemporary societies are driven by a culture of anxiety demanding a 'tough-on-crime' approach. The result has been a considerable increase of the prison population, changes in attitudes and perceptions towards 'criminals and delinquents' and the increasing use of technology for surveillance (for instance, cameras in public areas such as shopping centres) and private forms of security. The global ascendance of neoliberal ideologies and governance have also greatly contributed to this shift. Previous explanatory frameworks focused on the assumption that crime occurs due to lack of opportunities; an approach that sought to connect individual behaviour to structural factors. However, in the neoliberal culture of crime control, the focus has shifted towards explaining crime by individual deviance (Garland 2002).

As Wacquant (2011) has argued, the neoliberal state deals with the 'destructive consequences' of economic deregulation-such as the increase of poverty, marginality and exclusion-with violence against the lower classes:

[The neoliberal state] practices laissez-faire et laissez passer toward corporations and the upper class, at the level of the causes of inequality. But it is fiercely interventionist and authoritarian when it comes to dealing with the destructive consequences of economic deregulation for those at the lower end of the class and status spectrum. 
Thus, in effect, the neoliberal state does not 'retreat' from the social arena. Rather, social investment and the provision of job security is replaced with punitive measures as a new form of regulation and control of those who become structurally marginalised in the neoliberal economy (Antillano et al. 2016:198). Resistance against the effects of neoliberal policies by the lower and working classes is labelled as disorderly and threatening by the dominant classes, propelling the increased use of police and imprisonment in order to prevent the 'undermin[ing] the authority of the state' (Wacquant 2011). Underlying these policies and the ideological moral framing of them is a re-articulation of the culture of poverty (Lewis 1966), placing the burden of guilt upon the poor themselves. As Garland (2002:196) notes, poverty is attributed to 'lack of effort, reckless choices, a distinctive culture, a chosen conduct.' The individualising underlying tenant of neoliberal ideology reinforces such explanatory models. This leaves the poor in a situation whereby they not only have to bear the burden of being subjected to structural marginalisation as 'surplus' populations in a deregulated, precariatised economy, but they also have to bear ideologically and culturally codified stigmas of being 'unfit' and 'undesired' citizens in a 'sink or swim' ideological social order. For those who end up, guilty or not, in the prison system, the combined burden of structural and cultural-ideological marginalisation hits them with full force; they are considered as unwanted and deviant castaways from the desired social order altogether.

\section{Racialised Crime and Punishment}

Scholars have pointed out the overrepresentation in prison of persons belonging to certain racial groups or with other markers of distinction such as the colour of their skin (Hunter 2007; Bosworth et al. 2008; De Lissavoy 2013; Golash-Boza 2015). The racialised targeting of poor men is both an aspect of neoliberal approaches to crime prevention in their US configuration (see Goffman 2014) and an outcome of particular Latin American historical trajectories. Indeed, scholars have shown that the emergence of the modern prison in Latin America in the late nineteenth century aimed at abolishing traditional forms of punishment whilst maintaining racial and class divisions established in the colonial period (Salvatore and Aguirre 1996; Aguirre 2005). Hence, blacks and indigenous groups or persons with dark skin colour, who were at the bottom of Latin American societies and perceived as 'racially' inferior, populated the modern prisons in the late nineteenth century as well. 
The associations between poverty and 'racial otherness' established in colonial hierarchies are an important aspect of how this 'racialised' concept of the criminal poor has come into being. For example, Cynthia Milton (2007) shows how in eighteenth-century Ecuador policies introduced by the Spanish Crown to address poverty proscribed differential approaches depending on the 'racial' status of the poor in question. On the one hand, downwardly mobile Spanish elites could claim pobreza de solemnidad. The kind of assistance offered to such persons centred on maintaining their privileged position. In contrast, for persons of African or indigenous descent, poverty assistance involved various kinds of punishment; imprisonment, enclosure in a poorhouse or a home for wayward women (recogimiento) or forced labour. Thus, poverty was not neutral; instead, people were poor according to their class, 'race' and gender (Milton 2007:66-67). For the 'racially othered,' lower spectrums of society, then, the kinds of poverty assistance offered was difficult to distinguish from the deprivation of liberty handed out to criminals.

The long-term outcomes of such ideas and policies can be observed in contemporary Latin American societies. Despite numerous gains in identity politics and the challenging of racism on several fronts, notions of poverty and criminality remain 'racialised' (see, e.g. Ystanes (Chap. 4), this volume). It is well established that poverty discourse as well as poverty itself is gendered; women are both symbolically associated with poverty and carry the burden of poverty more often than do men (Broch-Due 1995). However, conceptualisations of the criminal poor are more strongly tied in with images of young men (Bourgois 2003; Goffman 2014; Ystanes (Chap. 4), this volume). Furthermore, the increasing 'talk of crime' (Caldeira 2000) permeating the media and the public sphere has 'naturalized some groups as dangerous' (Caldeira 2000:2) and accentuated public demands for tough-on-crime approaches. In the neoliberal configuration of crime prevention, this has led to 'racially othered,' poor men being the main targets of policing and punishment.

\section{Crime Control Policies in Honduras}

Honduras's current hard-line security agenda, known as mano dura ('iron fist'), is modelled after former New York mayor Giuliani's 'broken windows' policies (Müller 2009). The new security agenda has not only perpetuated the perception of poor unemployable young male adults as 
'criminals,' it has also led to severe changes in the institutions and legal frameworks dealing with crime, such as criminal codes, the police, the military and the penitentiary system.

The Honduran governments in the 1990s promoted mainly preventive policies towards violence and crime. Because most of the persons involved in crime and violence were adolescents and young adults, targeted preventive programmes were introduced in the form of awareness programmes in public schools focusing on drug use and gang memberships. Importantly, civil society organisations, youth organisations, local scholars and government officials attempted to draft a bill that directly addressed the mara phenomenon-Decree 141-2001 and 170-2001 known as the Law for Prevention, Rehabilitation and Reinsertion of Gang and Mara Members (Ley para la Prevención, Rehabilitación y Reinserción Social de Personas Integrantes de Pandillas o Maras). However, the bill was stalled in 2001, and the government opted instead for the hard-line security policies that are in force today. The new security agenda as of 2002 involves carrying out military and police raids in poor neighbourhoods (many of them controlled by gang members), the massive incarceration of 'criminals and delinquents' and changes in the criminal justice system-in particular an increase in sentences.

Although local gangs and maras initially had been involved in illegal activities (e.g. theft), these did not account for the rise of violence, insecurity and crime in the country. Rather, organised crime did (Rodgers 2009; Jüttersonke et al. 2009; UNODC 2012). Today, the maras are involved in the organised crime economy, but - to the extent that it is possible to establish comprehensive knowledge of this-hitherto mainly thought to be as associates further down in the food chain rather than as spiders in the web (Bosworth 2010:10).

However, through media representations conjuring up an imagery of gang and mara members as dangerous 'criminals' constituting a threat to Honduran society (Peetz 2011; Oetller et al. 2009), the government drummed up public approval for far-reaching reforms of penal and processual codes targeting the maras in particular. In August 2003, Congress reformed the 332 Article of the Penal Code, known as the Anti-gang Law. The new article declared gangs to be illicit associations, meaning that the sole membership of any gang was a motive for arrest and incarceration. This law works in tandem with the 2002 Law of Police and Social Co-Existence (Ley de Policia y Convivencia Social), which allows police to detain 'anyone suspicious or vagabonds' (Ungar and Salomón 2012:30). 
However, because it was not clear, from a legal standpoint, how to define membership to a gang, police and security agents had discretionary power to arrest anyone who appeared to be a gang member. In practice, this translated into the targeting of young males between 18 and 30 who had distinct markers, including the way they dressed (baggy jeans and T-shirts, sneakers), the way they carried their bodies (buzz cuts, shaved heads) as well as the use of piercings and tattoos. Because of this generalised targeting, gang members changed the way they dressed, covered their tattoos and resorted to other strategies for evading arrests (Gutiérrez Rivera 2010). However, the blurring of symbolic markers of gang membership led to new targeting practices directed against 'criminals' and 'delinquents,' centred mostly on young males' physical appearance such as skin colour.

\section{Gang Members’ Life Trajectories}

Studies of gang members' social background in Honduras indicate that they often are school dropouts from violent homes, living in neighbourhoods with low income levels, high degrees of social exclusion and scarce access to public services (Gutiérrez Rivera 2010:495). Consequently, they have limited venues for being socialised into 'normal' adulthood through a youth-to-adulthood transition passing from school and into the labour market (Fawcett 2001). This serve as 'push-factors' for 'street-corner' socialisation, which, in turn, increases the risk of becoming involved in criminal activities and the drug economy (see Strocka 2006 for an in-depth analysis of the multiple causes for gang formation in Latin America; see also Bourgois 2003 and Strønen 2014). Additionally, high levels of social distrust and the consumption of drugs and alcohol foment local social violence (Gutiérrez Rivera 2010:495). As Gutiérrez Rivera (2010:495) notes, 'gangs may thus impose local order or 'street level politics' through the use of violence, constituting a form of social structuration that undermines the existing local social fabric.' Gangs in Honduras, as in other Latin American countries, are highly territorialised. Different gangs control different territories, and gang members are with different degrees of rapport and animosity part of the local social fabric (Penglase 2010). It was exactly this territorial control and presence in marginalised neighbourhoods that the Honduran state's new security policies were aimed at breaking up, through constant raid carried out by the police and the military. As Gutiérrez Rivera (2010:497) has previously remarked: 
Mano Dura and the Anti-gang Law had a strong territorial component because they aimed at controlling a certain group (gang members) and territories (marginal neighbourhoods). Police and military forces raided gangcontrolled barrios looking for members hanging out on street corners and in their homes.

As noted above, the generalised targeting of 'deviant youth' through the anti-gang legislation prompts and justifies that arrests are being made at the officers' own discretion. Increases in arrests furthermore works in tandem with changes in the Processual Penal Code in 2002, which removed judges' discretionary powers of pre-trial detention (prisión preventiva). Previously, judges had discretionary power to decide whether to send suspect (or not) to a prison whilst waiting for the sentence. With the changes in the Processual Penal Code, everyone who was arrested was sent to prison to wait for their sentences. Furthermore, the time lapse between arrests and waiting for a sentence is considerable due to the inefficiency of the criminal justice system and Public Prosecutor's Office. Seen together, all these changes not only significantly increased the prison population, and by extension, the number of families whose lives were marked by various kinds of legal entanglements. It also led to an increase in the periods spent in prison whilst they wait for the sentence and, then, an increase in the time they spend in jail when they receive the sentence. The exception were inmates from the middle class or other inmates who could draw on considerable economic help from their family. These inmates hired lawyers and, in some cases, gave bribes to civil servants and judges in the Public Prosecutor's Office or the Criminal Courts to accelerate the trials and hearings.

As a result of these combined effects of the new security agenda, the prison population has increased significantly during the past two decades, collapsing the penitentiary system. Currently, 98 per cent of the inmate population is male (CIDH 2013).

\section{Bleak Futures}

In 2014, Gutiérrez Rivera interviewed inmates in the prison in the city of Comayagua. As other prisons in Honduras, the Comayagua prison is overcrowded and self-governed by inmates. During one visit, Gutiérrez Rivera met 'William', an inmate who had been in prison for 12 years and was hoping to be released that year because of good conduct. He was not sure 
though. 'Only God knows', he said. William appeared to be around 32-35 years of age. When asked what he would do when released, he said: 'Oh I don't know... I haven't thought about it. I mean, I need to see if I can find a job...,' his voice trailed off. On average, an inmate spent 8-10 years in the Comayagua prison.

William's lack of certainty about the future points to important questions concerning the consequences of mass incarceration of young, poor men. What lies ahead for them when released from prison? Will they be able to rebuild their lives after spending 5,10 or 15 years in prison? What long-term consequences will it have for Honduran society that such high numbers of already disadvantaged young men spend such a long time in prison without any possibilities for 'rehabilitation?' And how may we better understand the underlying rationale and structural underpinnings that legitimise such a punitive model?

The extended period that characterises prison life in Honduras reinforced the interruption of conventional youth-to-adulthood transitions set in motion by the neoliberal reforms. Youth unemployment rose significantly in Latin America in the 1990s (Fawcett 2001:3), and low-income youth were hit the hardest (Fawcett 2001:5). The changing structures in the labour market from the 1980s and onwards crowded out parts of the potential work force, particularly those on the bottom rungs of society. As Fawcett notes: "for many unskilled youth of Latin America, the distance between the average schooling level and the "needs of the market" is too far. There is no job pathway, which continually rewards a student in school, and keeps the students in school' (Fawcett 2001:16). This pattern was also present in Honduras. Large numbers of youth dropped out from the school system, which, as discussed above, makes them more vulnerable to ending up in the illegal street economy. A recent report shows that 23 per cent of the inmates in Honduran prisons are illiterate. Out of the 59 per cent of the inmate population that had access to primary education prior to entering the prison, only 26 per cent had actually finished primary school (CONAPREV 5 2011).

Several of the inmates that Gutiérrez Rivera interviewed had not completed primary school (which consists of 6 years). Even fewer inmates had enrolled in middle and secondary school. However, through ethnographic interviews, several of the inmates revealed that they would like to go back to school whilst in prison in order to have something lean on when they are released in the future. However, the only educational venue available to them is the EDUCATODOS programme, run by the 
Honduran Ministry of Education and the US development programme USAID. Despite being partially state-run, EDUCATODOS is not offered free of charge. Rather, parts of the programme are privatised and incur costs for the students. For example, USAID owns the copyright of the books and learning material, and all inmates enrolled by the programme have to buy their own copies. For many of the poor inmates, coming from poor households, this is a cost beyond their reach. Because of the high prices of the learning material, many inmates gave up on the idea of finishing school through the EDUCATODOS programme. 'Carlos', an inmate who had finished primary school, was eager to finish secondary school whilst serving his sentence. However, upon hearing that EDUCATODOS demanded payment for the books, he dropped the idea of enrolling.

I was going to organise a group because many of us [inmates] want to finish school. But I don't have money, we don't have money, not enough money to pay for the material. The little money I earn here is not enough. Nothing is free in prison, I have to pay for my bed, my space, food, everything. My family can't help either. They can't come here [to visit at the prison] because they live in Tegucigalpa and that means time and money, and they can't send me money either.

The other possibility for an inmate was to learn a skill from another inmates, such as carpentry, electric installation work or cooking. The Institute of Special Services for Prevention (Dirección General de Servicios Especiales Preventivos), part of the Ministry of Security, ran a programme for inmates who wanted to learn a skill in some of the prisons in Honduras; but the Comayagua prison was not one of them. Some inmates nevertheless organised the teaching of skill amongst themselves; however, this was highly subjected to the level of trust and tranquillity amongst prisoners. Neither was it of much worth to be 'self-taught' in prison when they had to search for work in a highly competitive labour market. As 'Manuel', an inmate who was scheduled to be released in four months, worded it:

I would like a job...in carpentry. I learned that here [in the prison]. [Other inmates] taught me... but you know, I don't know... I pray I can find a job. But I don't really if, you know, if anyone will hire me.

The limited access to education or professional training accentuated inmates' levels of uncertainty regarding their lives when released from 
prison. On the other hand, the long-term sentences served inside the prison wall contributed to strengthening their networks with other arrestees and convicted prisoners, as well as socialising them even further into the harsh rules of 'street corner society' — even within closed prison walls.

\section{The Self-Governed Prison}

As most prisons in Latin America, lack of funds and manpower have turned the Comayagua prison into self-governed prison (Darke and Karam 2016). The hierarchical prison order is governed by the Presidente or president of the inmates, followed by the vice president and the Jefe de Bartolinas or the boss of the blocks. All inmates start from below and are expected to comply with this self-governing regime which has established a 'prison order' (See Gutiérrez Rivera 2017). The president delegates other inmates to oversee prison life and the prison economy, which includes selling food, handicrafts, medicine, as well as illicit activities such as selling drugs and arms. As Carlos alluded to in the quote above, everything in the prison costs money: food, medicines, somewhere to sleep, protection and so on. The prison economy is an enclosed free-market sphere in the extreme; everything is commoditised, and the consequences of not being able to pay are harsh. The internal rule of law is maintained by violence and brutality, and the incumbent 'president' has to constantly demonstrate his willingness to subdue others by force in order to not be subjected to a coup or a mutiny.

This prison order is not unique for Honduras. Antillano et al. (2016) has carefully documented similar conditions in the prisons in Venezuela. Starting in the 1990s, Venezuelan prisons have increasingly been characterised by the retreat of state order and the ascendance of a complex self-governed prison hierarchy that is thriving on an illegal economy within and beyond prison walls. Venezuela's prison population rose significantly in the $1980 \mathrm{~s}$ and 1990s in line with increasing marginalisation and inequality under subsequent neoliberal regimes (see Strønen (Chap. 7), this volume). However, as Antillano et al. (2016) note, the current penal system in 'Bolivarian' Venezuela contradicts conventional wisdoms of a correlation between reduced socio-economic inequality and a milder punitive approach to crime and delinquency. Whilst Venezuela's prison population dipped significantly in the beginning of the twenty-first century-a period characterised by expansive pro-poor social policies and a political discourse emphasising structural explanatory models for crime - the prison population has been on a steady rise for the past near ten years (Antillano et al. 2016:200). 
In contrast to the neoliberal period-when the rise of the incarcerated population coincided with the increase in poverty, exclusion and inequalityduring Chavismo the relation seems to be inverse: a substantial improvement social indicators for the poor goes hand by hand with an increase in the penal population. (Antillano et al. 2016:201)

Antillano et al. (2016:2001) explain this apparent paradox through underlining the lopsided effects of social policies in the face of structural inequalities. Post-industrial societies, and not least rent-based countries such as Venezuela, continue to produce 'surplus' populations that 'remain excluded and marginalized and that are resistant to strategies of social inclusion' (p. 201).

Gledhill (2013) has also pointed out contradictions in the Brazilian state's security politics under the Lula and Rousseff administrations. As also noted in several of the chapters in this volume (Ystanes (Chap. 4), Sørbøe (Chap. 5), Costa (Chap. 3) and Lavros Pinta (Chap. 6)), these governments rolled out a series of reforms that effectively reduced poverty and inequality levels in the country. Yet so, security policies implemented in the major cities during their tenure were also characterised by the targeting of poor communities - and young men in particular. Above all, this included the increased police and military presence in impoverished communities and a 'war' against gangs involved in drug trafficking. Focusing in particular on policies rolled out in Salvador do Bahia aimed at detracting young men from entering into the consumption and trafficking of drugs, Gledhill writes that:

The danger of this focus is that it singles out particular communities as the source to delinquency and violence for the whole city, transforming their social problems stemming from poverty, the lack of clarity in land- and property rights, and the deficient infrastructure and life conditions, into the problems that threatens the security of all residents of the city. Such a "securitisation" of social problems runs the risk of brushing all the residents in these communities over the same comb. (Gledhill 2013:30, authors' translation from Spanish)

These comparative observations alert us to the structural underpinnings as well as cultural framing of 'mano dura' policies, regardless of political inclination right or left. Whilst Brazil, Honduras and Venezuela followed significantly different political trajectories during the Pink Tide époque, all three countries are carrying the legacy of long-term structural inequalities and marginalisation that has produced a 'surplus' population of primarily young, poor, coloured and unskilled male. In a de-proletarised economy, 
combined with the ascendance of a cross-border drug and crime economy across the Latin American continent, many of these young men end up in the penal system. Simultaneously, rising levels of violence and the pancontinental rise of the 'mano dura' approach consolidate public and political demands for taking a punitive, rather than rehabilitory stance, towards (real or perceived) criminal elements.

\section{FinAL ReFlections}

The US sociologist Alice Goffman speaks of two different trajectories that take persons from childhood to adulthood; one goes via the education system, the other goes via the penal system. As many young men in the neighbourhood she worked entered their late teens or early 20 s, 'the penal system has largely replaced the educational system as the key setting of young adulthood' (Goffman 2014:107). In the United States, it is mostly black men living in poor, segregated neighbourhoods that end up reaching adulthood via the penal system. This process reinforces 'racialised' socio-economic inequalities that the full granting of civil rights to African Americans was meant to eliminate. While other teenagers are freshmen or seniors in high school, the young men and boys Goffman worked with were defendants and inmates, spending time in courtrooms rather than classrooms, attending sentencing hearings and probation meetings rather than proms and graduations. As she notes:

As the criminal justice system has come to occupy a central place in their lives and by extension those of their partners and families, it has become a principal base around which they construct a meaningful social world. It is through their dealings with the police, the courts, the parole board, and the prisons that young men and those close to them work out who they are and who they are to each other. (Goffman 2014:107)

Of course, there are numerous differences between the Honduran and the US legal system, and the inmate-governed prisons in the former cannot meaningfully be compared to the highly securitised US prisons. Nevertheless, Goffman's work points to some important comparative parallels. The prison system itself serves as a centrifugal site for the socialisation of group membership cut off from 'official society.' Just as in the United States, inmates in Honduras are stuck in the punitive system during their most formative years, making it extremely difficult to rebuild their lives 
once they get out even if they should so wish. Moreover, just as the young, black men in Goffman's case, the Honduran prison population belongs to those groups in society that were crowded out from the educational system and the labour market in the first place. In sum, all of these features underline how structural processes, legal systems and punitive ideologies are conditioning the individual life trajectories and opportunities of the prison population.

By stressing this point, it is not our intention to underestimate the seriousness of crime and violence in the Latin America continent or to deprive criminal actors of a will and agency of their own. However, we contend that it is paramount to take a critical look at the historical trajectories, local/international political agendas and underlying racial and social profiling that propels and justifies hard-line security agendas. As Gledhill notes, it is necessary to look beyond the smoke screen created by the securitisation of poverty in order to capture social realities and power relations' (Gledhill 2013:53, authors' translation from Spanish), and ultimately, be able to create public policies that lead to permanent transformations. As this chapter has sought to address, the current 'iron fist' approach to crime in Honduras is taking place within a dense history of structural marginalisation, fuelled by the effects of the neoliberal era and its continuation up until today. Moreover, since the coup in 2009, these policies are taking place in the context of an escalating political proclivity to subdue unwanted social groups. Additionally, the US War on Drugs has contributed to a further violent and militarised persecution of real or perceived criminal elements, whilst the underlying factors and processes fuelling the drug economy are largely left unchallenged. Ultimately, this has resulted in a dramatic increase in the targeted incarceration of young, poor and dark-skinned men with few prospects for becoming inserted into an 'ordinary life' when they eventually are released from prison. This bodes for a perpetuation of, rather than a solution to, Honduras' security situation, which, in turn, will continue to reproduce the country's historically informed legacy of entrenched inequalities.

\section{Notes}

1. Koonings and Kruijt aptly point out that the 'new violence' means that 'a variety of social actors pursue a variety of objectives on the basis of coercive strategies and methods' (2004:8). This new form of violence is not directed towards the state, that is, to overthrow the status quo. Rather, it is a 
'democratisation' of violence (Koonings and Kruijt 2004; Rotker 2002) that can target anyone.

2. On the other hand, these neoliberal policies also entailed modernising the state institutions opening up for more citizen participation. For instance, human rights groups become more organised. The Honduran governments also attempted to increase youth participation through the creation of the National Institute of Youth (Instituto Nacional de Juventud) and the National Forum for Youth (Foro Nacional de Juventud).

3. The traditional elites and the military believed Zelaya wanted to change the constitution to allow re-election for a second term, which is prohibited in the current constitution. Ironically, Honduras's current president, Juan Orlando Hernández from the National Party, is also seeking to change the constitution to allow re-election. However, contrary to Zelaya, the traditional elites and the military have backed him. On 26 April 2015, the National Congress approved the re-election of the Honduran president.

4. There are also strong indicators of US complicity in the coup, see Beeton and Chun Tang (2016).

5. Comité Nacional de Prevención Contra La Tortura, Tratos Crueles Inhumanos o Degradantes,

\section{REFERENCES}

Aguirre, Carlos. 2005. The Criminals of Lima and Their Worlds: The Prison Experience (1850-1935). Durham: Duke University Press.

Antillano, Andrés, et al. 2016. The Venezuelan Prison: From Neoliberalism to the Bolivarian Revolution. Crime Law and Social Change 65: 195-211.

Beeton, Dan and Ming Chun Tang. 2016 Hillary's Role in Honduran Coup Sunk US Relations With Latin America to a New Low. Counterpunch, June 1. Available at http://www.counterpunch.org/2016/06/01/hillarys-role-inhonduran-coup-sunk-us-relations-with-latin-america-to-a-new-low/. Accessed 18 Apr 2017.

Blitzer, Jonathan. 2016. Should the U.S. Still Be Sending Military Aid to Honduras? The New Yorker, August 17. Available at http://www.newyorker. com/news/news-desk/should-the-u-s-still-be-sending-military-aid-to-honduras. Accessed 17 Apr 2017.

Bosworth, James. 2010. Honduras: Organized Crime Gaining Amid Political Crisis. Woodrow Wilson Center for International Scholars. Available at https:// www.wilsoncenter.org/sites/default/files/Bosworth.FIN.pdf. Accessed 18 Apr 2017.

Bosworth, Mary, B. Bowling, and M. Lee. 2008. Globalization, Ethnicity and Racism: An Introduction. Theoretical Criminology 12 (3): 263-273. 
Bourgois, Phillipe. 2003. In Search of Respect. Selling Crack in El Barrio. 2nd ed. Cambridge: Cambrigde University Press.

Broch-Due, Vigdis. 1995. Poverty Paradoxes: The Economy of Engendered Needs. Occasional Papers, The Nordic Africa Institute. Uppsala: Nordiska Afrikainstiuttet.

Bull, Benedicte. 2016. Governance in the Aftermath of Neoliberalism: Aid, Elites and State Capacity in Central America. Forum for Development Studies 43 (1): 89-111.

Bull, Benedicte, F. Castellacci, and Y. Kasahara. 2014. Business Groups and Transnational Capitalism in Central America. Economic and Political Strategies. Houndmills/Basingstoke/Hampshire: Palgrave Macmillan.

Caldeira, Teresa P.R. 2000. City of Walls. Crime, Segregation, and Citizenship in Sao Paulo. Berkeley: University of California Press.

CIDH. 2013. Informe sobre la situación de las personas privadas de libertad en Honduras. Documento 6 (18 de marzo), Organización de los Estados Americanos, Comisión Interamericana de Derechos Humanos. Available at https://www.oas.org/es/cidh/ppl/docs/pdf/HONDURAS-PPL-2013ESP. pdf. Accessed 18 Apr 2017.

CONAPREV. 2011. Diagnóstico del Sistema Pentienciario en Honduras. Comité Nacional de Prevención Contra la Tortura, Tratos Crueles, Inhumanos o Degradantes, Tegucigalpa, Honduras.

Darke, Sacha, and Maria Lucía Karam. 2016. Latin American Prisons. In Handbook on Prisons, ed. Y. Jewkes, J. Bennet, and Ben Crewe, 2nd ed., 460-474. Abingdon: Routledge.

De Lissavoy, Noah. 2013. Conceptualizing the Carceral Turn: Neoliberalism, Racism, and Violation. Critical Sociology 39 (5): 739-755.

Fawcett, Caroline. 2001. Latin American Youth in Transition: A Policy Paper on Youth Unemployment in Latin America and the Caribbean. Sustainable Development Department, Social Development Division, Labor Markets Policy Briefs Series, Inter-American Development Bank.

Garland, David. 2002. The Culture of Control: Crime and Social Order in Contemporary Society. Chicago: University of Chicago Press.

Gledhill, John. 2013. La mala administración de la seguridad pública. Revista de Antropología Social 22: 25-57.

Global Witness. 2017. Honduras. The Deadliest Place to Defend the Planet. London: Global Witness.

Goffman, Alice. 2014. On the Run: Fugitive Life in an American City. New York: Picador.

Golash-Boza, Tanya. 2015. Deported. Immigrant Policing, Disposable Labor, and Global Capitalism. New York/London: New York University Press.

Gordon, Todd, and J.R. Webber. 2011. Canada and the Honduran Coup. Bulletin of Latin American Research 30 (3): 328-342. 
Grosso, Joseph. 2014. The Honduras Drug War. Counterpunch, June 27. Available at http://www.counterpunch.org/2014/06/27/the-honduras-drug-war/. Accessed 17 Apr 2017.

Gutiérrez Rivera, Lirio. 2010. Discipline and Punish? Youth Gangs’ Response to 'Zero Tolerance' Policies in Honduras. Bulletin of Latin American Research 29 (4): 492-504.

- 2017. The World of the 'Rondines': Trust, Waiting and Time in a Latin American Prison. In Carceral Mobilities: Interrogating Movement in Incarceration, ed. Jennifer Turner and Kimberley Peters, 178-190. Abingdon: Routledge.

Hallinan, Conn. 2009. Honduran Coup: The U.S. Connection. Foreign Policy in Focus, August 5. Available at http://fpif.org/honduran_coup_the_us_connection/. Accessed 18 Apr 2017.

Hunter, Margaret. 2007. The Persistent Problem of Colorism: Skin Tone, Status, and Inequality. Sociology Compass 1 (1): 237-254.

ILO, International Labour Office. 2007. The Informal Economy. International Labour Office (ILO). Available at http://www.ilo.org/wcmsp5/groups/ public/---ed_norm/--relconf/documents/meetingdocument/wcms_ gb_298_esp_4_en.pdf. Accessed 20 Dec 2013.

Jüttersonke, Oliver, R. Muggah, and D. Rodgers. 2009. Gangs, Urban Violence, and Security Interventions in Central America. Security Dialogue 40 (4-5): 373-397.

Koonings, Kees, and Kruijt Dirk. 2004. Armed Actors, Organized Violence, and State Failure in Latin America: A Survey of Issues and Arguments. In Armed Actors. Organized Violence and State Failure in Latin America, ed. Kees Koonings and Dirk Kruijt, 5-15. London: Zed Books.

Larkins, Erika M. Robb. 2015. The Spectacular Favela: Violence in Modern Brazil. Oakland: University of California Press.

Lewis, Oscar. 1966. La Vida: A Puerto Rican Family in the Culture of Poverty. San Juan/New York: Random House.

Milton, Cynthia E. 2007. The Many Meanings of Poverty. Colonialism, Social Compacts, and Assistance in Eighteenth-Century Ecuador. Stanford: Stanford University Press.

Müller, Markus-Michael. 2009. Wenn Null Toleranz und Zebrochene Fensterscheiben auf Reisen gehen: Globalisierung und die Restrukturierung des historichen Zentrums in Mexiko Stadt. Kriminologisches Journal 41 (2): 82-99.

Oetller, Anika, Sebastian Huhn, and Peter Peetz. 2009. Contemporary Discourses on Violence in Central American Newspapers. International Communication Gazette 71 (4): 243-261.

Peetz, Peter. 2011. Maras, Medien, Militär. Gesellschaftlicher Diskurs und staatliche Politik gegenüber Jugendbanden in Honduras. Münster: LIT Verlag. 
Penglase, Ben. 2010. The Owner of the Hill: Masculinity and Drug-trafficking in Rio de Janeiro, Brazil. The Journal of Latin American and Caribbean Anthropology 15 (2): 317-337.

Portes, Alejandro, and Kelly Hoffman. 2003. Latin American Class Structures: Their Composition and Change During the Neoliberal Era. Latin American Research Review 38 (1): 41-82.

Robinson, William I. 2003. Transnational Conflicts. Central America, Social Change, and Globalization. London: Verso.

Rodgers, Dennis. 2009. Slum Wars of the 21st Century: Gangs, Mano Dura and the New Urban Geography of Conflict in Central America. Development and Change 40 (5): 949-976.

Rotker, Susana, ed. 2002. Citizens of Fear: Urban Violence in Latin America. New Brunswick: Rutgers University Press.

Salomón, Leticia. 1994. La Violencia en Honduras, 1980-1993. Tegucigalpa: CEDOH (Centro de Documentación de Honduras).

Salomón, Leticia, Julieta Castellanos, and Mirna Flores. 1999. La delincuencia juvenil: Los menores infractores en Honduras. Tegucigalpa: CEDOH (Centro de Documentación de Honduras).

Salvatore, Ricardo, and Carlos Aguirre. 1996. The Birth of the Penitentiary in Latin America: Toward an Interpretative Social History of Prisons. In The Birth of the Penitentiary in Latin America. Essays on Criminology, Prison Reform, and Social Control, 1830-1940, ed. R. Salvatore and C. Aguirre, 1-22. Austin: University of Texas Press.

Shipley, Taylor. 2016. "Not a Single Crack Where the Light Can Come In." Civilmilitary Relations in Contemporary Honduras, CMI Working Paper 2016(1). Bergen: Chr. Michelsen Institute.

Stepan, N.L. 1991. The Hour of Eugenics'. Race, Gender, and Nation in Latin America. Ithaca/London: Cornell University Press.

Strocka, Cordula. 2006. Youth Gangs in Latin America. SAIS Review of International Affairs 26 (2): 133-146.

Strønen, Iselin. 2014. The Revolutionary Petro-state. Change, Continuity, and Popular Politics in Venezuela. PhD Dissertation, The University of Bergen.

UNDP. 2014. Human Development Report 2014. Sustaining Human Progress: Reducing Vulnerabilities and Building Resilience. New York: United Nations Development Programme.

Ungar, Mark, and Leticia Salomón. 2012. Community Policing in Honduras: Local Impacts of a National Program. Policing and Society 22 (1): 28-42.

UNODC. 2012. Transnational Organized Crime in Central America and the Caribbean. A Threat Assessment. Vienna: United Nations Office on Drugs and Crime.

Wacquant, Loïc. 2009. Punishing the Poor: The Neoliberal Government of Social Insecurity. Durham: Duke University Press. 
2011. The Punitive Regulation of Poverty in the Neoliberal Age. Open Democracy. Available at https://www.opendemocracy.net/5050/lö̈c-wacquant/ punitive-regulation-of-poverty-in-neoliberal-age. Accessed 24 Mar 2017.

World Prison Brief. 2016. Honduras. World Prison Brief. Available at http:// www.prisonstudies.org/country/honduras. Accessed 30 Mar 2017.

Ziccardi, Alicia. 2008. Pobreza y exclusión social en las ciudades del siglo XXI. In Procesos de Urbanización de la Pobreza y Nuevas Formas de Exclusión Social, ed. A. Ziccardi. Bogotá: Siglo del Hombre Editores and CLACSO-CROP.

Open Access This chapter is licensed under the terms of the Creative Commons Attribution 4.0 International License (http://creativecommons.org/licenses/ by $/ 4.0 /$ ), which permits use, sharing, adaptation, distribution and reproduction in any medium or format, as long as you give appropriate credit to the original author(s) and the source, provide a link to the Creative Commons license and indicate if changes were made.

The images or other third party material in this chapter are included in the chapter's Creative Commons license, unless indicated otherwise in a credit line to the material. If material is not included in the chapter's Creative Commons license and your intended use is not permitted by statutory regulation or exceeds the permitted use, you will need to obtain permission directly from the copyright holder.

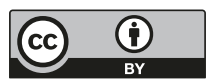

